\title{
Religion in Creating Populist Appeal: Islamist Populism and Civilizationism in the Friday Sermons of Turkey's Diyanet
}

\author{
Ihsan Yilmaz $^{1, *(\mathbb{D})}$, Mustafa Demir ${ }^{2}(\mathbb{D})$ and Nicholas Morieson ${ }^{3}$ (D) \\ 1 Alfred Deakin Institute for Citizenship and Globalization, Deakin University, Melbourne, VIC 3215, Australia \\ 2 European Center for Populism Studies, 1050 Brussels, Belgium; mdemir@populismstudies.org \\ 3 The Institute for Religion, Politics and Society, Australian Catholic University, \\ Melbourne, VIC 3065, Australia; Nicholas.Morieson@acu.edu.au \\ * Correspondence: ihsan.yilmaz@deakin.edu.au
}

check for updates

Citation: Yilmaz, Ihsan, Mustafa Demir, and Nicholas Morieson. 2021. Religion in Creating Populist Appeal: Islamist Populism and Civilizationism in the Friday Sermons of Turkey's Diyanet. Religions 12: 359. https:// doi.org/10.3390/rel12050359

Academic Editor: Jocelyne Cesari

Received: 20 April 2021

Accepted: 12 May 2021

Published: 18 May 2021

Publisher's Note: MDPI stays neutral with regard to jurisdictional claims in published maps and institutional affiliations.

Copyright: (c) 2021 by the authors. Licensee MDPI, Basel, Switzerland. This article is an open access article distributed under the terms and conditions of the Creative Commons Attribution (CC BY) license (https:/ / creativecommons.org/licenses/by/ $4.0 /)$.
Abstract: Drawing on the extant literature on populism, we aim to flesh out how populists in power utilize religion and related state resources in setting up aggressive, multidimensional religious populist "us" versus "them" binaries. We focus on Turkey as our case and argue that by instrumentalizing the Diyanet (Turkey's Presidency of Religious Affairs), the authoritarian Islamists in power have been able to consolidate manufactured populist dichotomies via the Diyanet's weekly Friday sermons. Populists' control and use of a state institution to propagate populist civilizationist narratives and construct antagonistic binaries are underexamined in the literature. Therefore, by examining Turkish populists' use of the Diyanet, this paper will make a general contribution to the extant literature on religion and populism. Furthermore, by analyzing the Diyanet's weekly Friday sermons from the last ten years we demonstrate how different aspects of populism-its horizontal, vertical, and civilizational dimensions-have become embedded in the Diyanet's Friday sermons. Equally, this paper shows how these sermons have been tailored to facilitate the populist appeal of Erdoğan's Islamist regime. Through the Friday sermons, the majority-Sunni Muslim Turks are presented with statements that evoke negative emotions and play on their specific fears, their sense of victimhood and through which their anxieties - real and imagined-are revived and used to construct populist binaries to construct and mobilize the people in support of an authoritarian Islamist regime purported to be fighting a "civilizational enemy" on behalf of "the people". Finally, drawing on insights from the Turkish case, we illustrate how the "hosting" function of the civilizational aspect plays a vital role in tailoring internal (vertical and horizontal) religious populist binaries.

Keywords: populism; religion; Turkey; Erdoğan; Islamist populism; Islamist civilizationism; Diyanet; Friday sermons

\section{Introduction}

The impact of religion and religious identity on politics has become increasingly evident since the turn of the millennium. The influence of religion is especially apparent in the populist rhetoric now conspicuous in political life across the world. Populist political actors from Western Europe to Asia to the Americas are deploying religious notions and emotions to appeal to and /or construct "the people", and to mobilize them into backing the populists" fight against established norms and institutions. In Turkey, Recep Erdoğan invokes Islamist ideas to divide the population between Muslims (the ummah) and their enemies, and in doing so mobilizes support for his party's global Islamist agenda (Yilmaz and Bashirov 2018); in India, Narendra Modi combines religion with nationalism to unite the Hindu population and galvanize support for the Bharatiya Janata Party (BJP) in its fight against "the other": elites, religious minorities (especially Muslims), and established democratic rules and institutions (Kinnvall 2019; Peker 2019). In the United States, "Christianism" became the fundamental building-block of Trump's populist discourse, which openly discriminated against Muslims (Haynes 2020), the designated enemy that "hates 'us"" (CNN 2016); and 
in Europe the anti-immigrant, xenophobic policies of radical right populist parties are communicated with references to religious identity (Roy 2016; Ozzano and Bolzonar 2020; Morieson 2021). However, as far as we can see, only one of these populist leaders/parties uses state institution(s) systematically to disseminating their religious populist rhetoric and appeal: Recep Erdoğan of Turkey.

Taking the exceptionality of the Turkish case as its point of departure, this paper focuses on Islamist populism in Turkey under the rule of the AKP and its leader Recep Erdoğan, who assumed power at a national level in 2003 and has ruled either as Prime Minister or, later, President since. Thus, Turkey is an illustrative case with which we can examine how religious populism operates when in power. Specifically, we examine how Islamists were able to capture and redesign relevant Turkish state institutions, turning them into propaganda machines able to construct antagonistic binaries upon which the AKP could base its populist appeal.

In this paper, Islamism is understood as politicized version of religion of Islam, a counter-hegemonic paradigm, which 'refers to turning religion into an ideology and an instrumental use of Islam in politics ... by individuals, groups and organizations in order to pursue political objectives' (Yilmaz 2021, p. 104). It is also important to note that 'Islamism is not a coherent ideology - it focuses on identity politics rather than ideas and an appeal to emotions rather than intellect' (Yilmaz 2021, p. 105).

The paper aims to demonstrate how religious ideas and identities are employed in the weekly Friday sermons of the Diyanet to create antagonistic binaries in multiple ways: horizontal, vertical, and civilizational. Additionally, we expose the hosting function ${ }^{1}$ of the civilizational aspect, which has become increasingly prominent in the Diyanet's Friday sermons. $^{2}$

The role of the state institution of the Diyanet in manufacturing populist appeal through its Friday sermons is an understudied phenomenon. By studying these weekly sermons through the lens of populism, we address this gap in the emerging literature on the Diyanet. This article begins with a description of populism and its three variants or aspects: vertical, horizontal, and civilizational. The second section describes the rise of Erdoğanist Islamist populism in Turkey. The third section examines the weekly Friday sermons to illustrate how the Diyanet assists the Erdoğanist regime in constructing and propagating multidimensional (vertical, horizontal, and civilizational) populist binaries in Turkey, and how the civilizational aspect functions as a host for the other two.

\section{Populism and Its Variants: Horizontal, Vertical, and Civilizational Aspects}

While populism remains a contested concept, scholars typically examine populist phenomena through one of four major approaches. Populism is perhaps most often described as a set of ideas, perhaps even a "thin ideology" (Mudde 2017), which can be affixed to another "thick" ideology. According to this approach, populism sets "the pure people" against a "corrupt elite", and "argues that politics should be an expression of the volonté générale (general will) of the people" (Mudde 2004, p. 543). Another approach describes populism as a type of discourse used by political actors across the world that can be combined with almost any existing political ideology (Jagers and Walgrave 2007). Populist discourse, according to many scholars who use this approach, involves at its core an "appeal to the people" (Poblete 2015, p. 204).

Another approach describes populism as a devised strategy (Barr 2009) able to revise the existing system and capture the state. While for some others, it is a political style or performance (Moffit 2017). Despite these differences and the existence of different populisms, almost all scholars of populism concur that populism creates antagonistic binaries and that populist leaders portray themselves as saviors of "the people", defenders of the victimized little people against evil and the corrupt elite. This is an attempt to turn politics into a struggle between the forces of good and evil, where the good is represented by the populists who are the only legitimate representatives of the people. Notwithstanding its competing definitions, and leaving its ontological nature to the discussion in the extant 
literature, we see that populism is about constructions (construction, de-construction, and re-construction) of "the people(s)", and mobilization in an antagonistic fashion by populists, because the construction of "the people" is "the main task" of populists (Laclau 2006; Wojczewski 2020; Katsambekis 2020).

Taguieff (1995, pp. 32-35) observes populism as having two dimensions, vertical and horizontal. In its vertical dimension, populism divides "us" ("the people") and "them" ("the corrupt elite"). The horizontal dimension divides the people into "the pure people" of the land and "the evil traitors", unwanted citizens excluded from the conception of "the people". Brubaker (2017) contributes to the discussion by identifying a new dimension, civilizational. He remarks that populists perceive that alongside groups and parties with physical/personal existence, there are "impersonal forces or institutions that are threatening our way of life or our security: globalization, unfettered trade, the European Union (EU), radical Islam, and so on" (Brubaker 2017, p. 1192). These transnational or international forces threatening the people can be framed by populists as civilizational threats, and not merely threats to the nation. In doing so, the people can be defined in civilizational terms, as can the people and institutions that threaten them. Thus, the civilizational aspect can be particularly important in aiding the construction of the people and the designated enemies: a constructed people require a civilization with which to identify, and a real enemy always conspiring against the people, either directly or indirectly through its collaborators.

Civilizationist populism puts less emphasis on national differences and more on civilizational distinctions, especially religions and cultural legacies (Brubaker 2017, p. 1211). In civilizational populism, religion emerges as a political identity defined by its other; that is, by perceived oppositional civilizations. Brubaker argues that right-wing populists in Europe converged towards each other, embracing civilizationalism, due to a shared anxious preoccupation with an imagined civilizational threat from Islam. This anxious "preoccupation with Islam has given rise to an identitarian 'Christianism', a secularist posture, a philosemitic stance, and an ostensibly liberal defense of gender equality, gay rights, and freedom of speech" (Brubaker 2017, p. 1193). Thus, while civilizationism can still be "understood as a form of nationalism, the boundaries of belonging and the semantics of self and other are reconceptualized in civilizational terms, then one can speak of an alternative to nationalism" (Brubaker 2017, p. 1211). In this civilizationalist discourse, the imagined community or nostalgic utopian home is "located at a different level of cultural and political space than national discourse" (Brubaker 2017, p. 1211). Civilizationism is an alternative principle of vision and division of the world, but it does not supersede nationalism, rather it combines the two forces (Brubaker 2017, p. 1211). In relation to populist politics, civilizationism (civilizationist rhetoric) in the hands of populist actors serves as a highly effective emotional instrument of division and a galvanizer of popular support.

The relationship between populism and religion, as a source and generator of "civilizational values", is an emerging phenomenon drawing scholarly attention (Marzouki et al. 2016). Religion provides a fertile ground, not only in constructing a receptive audience, "the pure people" of the populists, but also it is relevant and highly valuable for setting up "us" versus "them" dichotomies and perpetuating these divisive binaries (Roy 2016; Zúquete 2017; Yilmaz and Bashirov 2018).

Islamism, too, is a civilizationist phenomenon (Yilmaz 2021, p. 128). Its survival and maintenance are highly dependent on the level of antagonism between Islam and its "other", the Judeo-Christian West. Thus, as Tugal observes, Islamism is "a multivalent religio-moral populism - a potentially explosive articulation of different class interests and religious cravings" (Tuğal 2002, p. 86). Islamist populism, therefore, takes the form of the mobilization of Islamist elements in the form of the people.

Recently, populism has been widely adopted to frame the political activities of the Erdoğan regime (Selçuk 2016; Yabanci 2016; Kirdiş and Drhimeur 2016; Özpek and Yaşar 2018; Yilmaz 2018; Castaldo 2018; Özçetin 2019; Sawae 2020; Tas 2020), especially in studies of Erdoğan's populist framing of political crises (Türk 2018). Moreover, there are studies 
looking at the role of religion in the populist appeals of Erdoğan's AKP and analysis of the religious references in his regimes' populist narratives (Yabanci and Taleski 2018; Yabanci 2020). There is also an emerging literature on the Diyanet and its political activities; however, this either discusses how the Diyanet is used as or transformed into a political instrument to control the religious sphere and transform the sociology in line with the agenda of the hegemon political power in Turkey (Gözaydın 2008; Öktem 2012; Lord 2018; Öztürk 2018; Adak 2021); or discusses how it is utilized by the current Turkish regime in foreign relations/policy to increase soft-power (Öztürk and Sözeri 2018); or the Diyanet's activities through the lenses of desecularization (Adak 2021). However, the role of the Diyanet in constructing an Islamist populist appeal has not been systematically studied. This paper addresses this gap in the literature.

\section{Rise of Erdoğanist Islamist Populism}

After running a pro-EU reformist government in its first few years, from 2002 to 2008, Turkey's ruling party, AKP (Justice and Development Party), has gradually shifted towards authoritarianism. This was deeply felt during the Gezi protests in the summer of 2013 and became an indisputable reality after the failed coup attempt in 2016. To continue its authoritarian rule and maintain popular support, the regime has tailored a certain type of populism for its use, a populism hosted by what we call "Islamist civilizationism", a term inspired by Brubaker's civilizationist populism (Brubaker 2017).

Erdoğan's transformation into an Islamist populist manifested during the Gezi Protests in the summer of 2013, when vast numbers of Turkish citizens protested against a variety of political and social issues, most prominently the increasing authoritarianism of the ruling AKP (Dinçşahin 2012; Bozkurt 2013; Aytaç and Öniş 2014; Yilmaz 2015; Günay and Dzihic 2016; Selçuk 2016; Türk 2018). Since the protests, Erdoğan has made a political appeal to his Islamist people via strong anti-Western rhetoric full of conspiracy theories (Yilmaz and Bashirov 2018). So powerful has this appeal proven that Erdoğan's Islamist narratives have even been adopted by segments of his political opposition (Yilmaz et al. 2020). Erdoğan's Islamist narrative begins by defining the West as the ultimate "other", and designates it the source of Turkey's (and, more broadly, Muslims') historical fears, and insecurities. Erdoğan's construction of the people is therefore contingent upon the construction of the West as "the enemy", and a traditional opponent upon which all sorts of real or imagined crimes against Muslims can be blamed. Having constructed an enemy, the regime invites Turkish citizens to rally behind Erdoğan and support him in his fight against the oppression and victimization of Muslims at home and all around the world.

Friday sermons have played a crucial role in conveying these "constructed" narratives. In the Turkish case, narratives of victimhood play an important role. A victimhood narrative has been a strong component of Turkish Islamist narratives since the early Republican era, and was transmitted to Erbakan's Islamist populism, and later inherited by the AKP in regards to the Kemalist hegemony (Yilmaz 2021, pp. 107-8). Turkish Islamist victimhood discourse rests on the argument that Islamists have been "the true 'victims' of modernization and of the related secularization processes in Turkey" (Yilmaz 2017, p. 483). At the heart of the Turkish Islamist victimhood imagination lies the troublesome destruction of the Ottoman State and establishment of the secular Republic in 1923. The early Kemalist reforms in education, social, and political life of Turkey dealt a dramatic blow to the status and wealth of the Islamic establishment. However, unlike the earlier Turkish Islamist populism, until the Gezi protests in 2013, AKP's populism did not include anti-Westernist elements. The party initially needed the support of the pro-EU groups and actors in Turkey as well as the support of Western states, institutions, groups, and media as leverage against the Kemalist tutelage. All this would change with the Gezi protests, by which time the AKP had already consolidated its power, sidelined the Kemalist tutelage, and become the dominant party in Turkey. Having overcome the Gezi protestors, the AKP no longer needed the support of the EU, whose pressure for democratization, anticorruption legislation, and 
transparency the party rejected. Transactionalist relations with the EU would be enough for the AKP (see in detail Bashirov and Y1lmaz 2020). Therefore, from 2013, the party was free to indulge in victimhood narratives pitting the West against Turkey and, more broadly, Muslims worldwide.

In addition to exploiting existing Turkish Islamist Victimhood narratives, the AKP's victimhood narrative had its own imaginary dimensions. During its first two terms, the AKP's victimhood discourses successfully focused on Kemalist-era policies, such as the 28 February 1997 coup, the headscarf ban and discrimination in the bureaucratic and military sectors, as well as the long-standing discrimination faced by minorities (Kurds, Alevis, and non-Muslims) (see Açıkel 1996; Demiralp 2012; Yilmaz 2017; Grigoriadis and Dilek 2018). This was an era of victimhood based on real events and needed no support from conspiracy theories. In the post-Gezi period, as a result of the collapse of the coalition supporting the $\mathrm{AKP}$ and the party's emergence as the hegemonic party after its third general election victory, the AKP established an imaginary victimhood narrative and employed anti-Western conspiracy theories to explain away its failures, inefficiencies, and other problems.

The AKP's imagined international conspiracy against Turkey has been framed in partly civilizational terms. According to the narrative, Turkish "citizen enemies" (Umar 2019) and their international collaborators are Islamophobes conspiring not only against Turkey but against "the Muslim people" all over the world. Inspired by Brubaker (2017), we call this form of populism "Islamist Civilizationism", which "has a paradoxical intermingling of Turkish nationalism and Islamist civilizationism and is linked to Pan-Islamism" (Yilmaz 2021, p. 155).

In this paper, we explore how religion-in this case Islam-is employed in the populist politics of the Erdoğanist regime to construct "the morally superior pure people" and "the enemy" via the Diyanet and its weekly Friday sermons. We argue that Friday sermons have been incrementally employed by the regime, and used to advance its political agenda through the exploitation of the fears, insecurities, and anxieties of the majority Muslim people of Turkey. Framing the Turkish case using these concepts, we argue that the regime has applied all three dimensions of populism: vertical, horizontal, and civilizationalist. We further argue that the Erdoğanist regime frames the vertical and horizontal binaries with reference to the civilizational aspect. Therefore, we call the civilizational dimension the "host dimension" of Erdoğan's Islamist populism, with reference to the definition of populism as a "thin-centered ideology" that "could be combined with other beliefs and ideas of politics" (Canovan 2002, p. 32). In other words, the civilizational aspect of Islamist populism helps Turkish populist Erdoğan fortify his thin-centered horizontally and vertically manufactured populist binaries.

Examining the AKP's narratives, we find three aspects of populism: vertical, horizontal, and civilizational, each corresponding to different phases of Erdoğan's era in Turkey. In their first term, Erdoğan and his AKP emerged as a liberal, democratizing force fighting vertically against the Kemalist "tutelage", claiming to represent those who had been the "undesired citizens" (nonsecular practicing Muslims, Kurds, Alevis, any religious and ethnic minorities refusing to abandon their identities, in favor of the official secular Muslim Turkish identity) of the country for decades. Erdoğan promised to reform the state to "emancipate" these people from Kemalist tutelage. Using this rhetoric, he managed to rally the support of diverse segments of society, from left to right, Kurds to Alevis, and from other ethnic and religious minorities. In his second phase, Erdoğan turned on Kemalist white Turks and launched a horizontal fight against them to remove them from their privileged positions, announcing that "in this country there is a segregation of Black Turks and White Turks. Your brother Tayyip belongs to the Black Turks." This fight helped him consolidate his conservative constituency. Later, during the Gezi Protests, Erdoğan first asked protestors to stop, warning them that "Patience has its limits ... if you have a problem, you can choose your representatives." He threatened these protesters by claiming that he was struggling to "retain home" the $50 \%$ of the population who supported him in relation to people gathered in Gezi, he also said, 
"Are the people only those at Gezi Park? Aren't those who came to meet us at Istanbul airport people too? Those who are gathered now in Ankara; aren't they people, too?" Erdoğan asked, calling on the protesters to face off in local elections next year. "Instead of [occupying] Gezi Park or Kuğulu Park [in Ankara], there are seven months [until the elections]. Be patient and let's face off at the ballot box" (Hurriyet 2013).

In the final stage, he shifted into a dimension in which political discussion is shaped by civilizational terms. He also successfully linked, in this final stage, previous populist binaries to manufactured civilizational dichotomies. In other words, to maintain and legitimize the constructed binaries created in the AKP's first two terms of government, the regime began to portray its designated enemies (leftists, liberals, democrats, and most of the urban educated people, "disloyal" Kurds, "disloyal" Alevis, "disloyal" Muslim groups, any other minority groups, in short, anyone critical of Erdoğanist regime) as extensions of or collaborators with the people's civilizational enemy: the Judeo-Christian West. In this way, the civilizational aspect of Erdoğan's populism hosts the other vertical and horizontal aspects, and uses religious identity to elevate the AKP's populist narrative to the level of international politics and the clash of civilizations.

\section{How Do the Diyanet's Friday Sermons Construct and Propagate Erdoğanist Populism}

In the early years of the Turkish Republic, the Diyanet was established to communicate with the majority devout Muslim population of the country and gradually transform them into the desired citizens of the modern Republic: secular Turkish Muslims (Yilmaz 2021, p. 89). The first step towards accomplishing this goal was creating a national religion, Turkish Islam, to "protect the Turkish national identity" (Zürcher and van der Linden 2004, p. 110; Poulton 1997, pp. 185-87; Sunier et al. 2016, p. 406). Under the Kemalist hegemony, the Diyanet was a promoter of sovereignty, national unity, and freedom, and it glorified the founding father of Turkey. When the Islamist AKP came to power in 2002, instead of eliminating this institute, they ironically captured and widened its capacity, ${ }^{3}$ boosting it financially and employing it to create an Islamist populist appeal.

Weekly Friday prayers have been considered by both Kemalists and Islamists as a very important tool to control Turkish citizens' perspective about Islam and to construct the good citizens. Friday as a day and Friday prayer as a ritual has a significant place in the Muslim religious life. Mid-day prayer on Friday was replaced by Friday prayer, and the sermons are an inseparable aspect of this weekly prayer. Thus, a proper Friday prayer necessitates delivering the sermon. Today in Turkey, in more than 90 thousand statecontrolled mosques, it is estimated that more than 15 million male citizens are participating in weekly Friday prayers as the audience of Friday sermons (Haber Turk 2015). Friday sermons continue to have a special religious status among Muslims, and attendees are forbidden to speak among themselves during the delivery of sermons; anyone else who speaks, or even asks another person not to speak, will be acting against the Islamic law. Therefore, more than a discussion or speech, it is delivered in the form of impositions in a top-down fashion.

The Friday sermons manufacture vertical and horizontal binaries with reference to dichotomies set at civilizational dimensions. Therefore, we begin by examining the vertical and horizontal binaries embedded in the sermons, and then examine the civilizational binaries, which ultimately host the vertical and horizontal binaries.

\subsection{Vertical Aspect}

The founding secular elite of the Republic saw religion (the role of religion in state and society) as an obstacle to modernization and progress (Kili 1980). Therefore, they opposed Islamists' ambitions of "reviving" Islam and leading and protecting the Muslim ummah ( Göle 1997; Berkes 1999). Rather, they approached Islam from an identarian perspective and as something that could be used in the construction of a national identity (Yilmaz 2005). On the other hand, in the Islamist narrative, the secularist Kemalist establishment of the Republic is depicted as a collaboration with the West, "the existential enemy" of Muslims. 
The modernization efforts of the secular establishment were correspondingly perceived as collaborations with the Christian West to eliminate Islam and Muslims from the Turkish public sphere. However, the Diyanet, founded by the Kemalist establishment in the early years of the Republic, always kept itself away from these Islamist narratives of collaboration and victimhood. However, this began to change when the AKP won government.

Under the AKP regime, the Diyanet's approach to Kemal Ataturk, the founder of the Republic, and to national commemorations has altered considerably, provoking concern and opposition from the Kemalist Republican Party (CHP). For example, the Diyanet's narrative in relation to the 29 October Republic Day celebrations is a stunning example of the Diyanet's "new" approach to the country's secular identity and values. The Friday sermon on Republic Day traditionally celebrated the secular holiday. Yet in 2010, when a new President of Religious Affairs was appointed, Republic Day was only commemorated at the very end of the sermon. In 2013, all mention of Republic Day was avoided, and in Friday sermons since, any celebration of the day has been absent. Atatürk's name was also removed from sermons. In addition, celebration of 30 August, Victory Day, was also dropped from the Diyanet's agenda from 2015, although it was cited again in 2018 with new updates. In two sermons, read in 2013 and 2014, on the occasion of the Great Offensive (Buyuk Taarruz) and the Battle of the Commander-in-Chief, which historically commemorated Atatürk, the following passage appeared:

Because human beings can be dragged into sin after victories. After success, he can succumb to his soul. He forgets that it is God who has given these successes and who has achieved these victories, and he attempts to take credit for himself. He separates himself from the truth, justice, and law.

This statement deliberately downplays the share of Atatürk's military skills in the Commander-in-Chief Battle (in the 1920s against the Greeks). While the Great Offensive was mentioned again in Friday sermons in 2018, this does not mean that the Diyanet has stepped back from its antisecular, anti-Kemalist positions. In 2019, Victory Day—which commemorates the Great Offensive- occurred on a Friday and thus coincided with Friday sermons, yet when it was mentioned, Atatürk's name was absent.

More recently, during the re-opening of the Hagia Sofia Museum as a Mosque, on a Friday 2020, the head of the Diyanet Ali Erbaş himself delivered the sermon. He made an indirect negative reference to Ataturk, who had converted the Hagia Sofia from a Mosque to a Museum, which proved controversial and caused discontent on opposition benches at the time. Erbaş reminded the thousands in the mosque, and millions of Muslims watching live across the world, that the Hagia Sophia was donated as a mosque by Sultan Mehmed the Conqueror, who conquered Istanbul. He also stated that,

In our belief, charity properties are inviolable, it burns the person who touches it; the one who breaks it [Mustafa Kemal Ataturk] suffers the curse. The conditions given by the one who donated it [the philanthropist, Sultan Mehmed the Conqueror] is a must to be observed.

The opposition parties reacted negatively to the "curse on Atatürk" in this sermon. Upon seeing these reactions, Erbaş made a statement and stated that with these words he was not merely referring to the Hagia Sofia, nor to any events that had occurred in the past, but rather cursed future individuals who may break trust with the people (Hurriyet 2020).

Regardless of the true meaning of Erbaş' sermon, his words are part of a wider campaign to attack Turkish secular elites past and present. The AKP portrays Kemalists "as elites who are out of touch with the 'real', authentic values of 'the people', charge them with visiting historical horrors on simple people in the name of Westernization or progress" (Çapan and Zarakol 2019, p. 276). The Erdoğanist regimes' populist fight against the main opposition party, the CHP-regarded as "the castle of Kemalism"—is part of the wider attack on the secular elites the AKP regard as civilizational traitors. Under AKP rule, the Diyanet sermons have also contributed to the process of building the Islamic ummah identity against the secular Turkish identity. Diyanet sermons often associate 
secularists with the Kemalist establishment, which is in turn constructed as the enemy of the Muslim people, or the ummah. In a sermon dated 20 June 2014, the congregation is told that the most important duty in this life is to give an identity to their children, and to raise them as "servants to Allah, ummah to Muhammad Mustafa (pbuh), and virtuous people equipped with the values of Islam." ${ }^{4}$ It should also be noted that while the Islamic ummah is emphasized in the sermons, the sub-identity of the "nation" is used only in an inclusive way, and it is not shown as an alternative to the identity of the "ummah".

The Diyanet was founded by the Kemalist establishment in the early years of the Republic, and for decades, it reflected the founders' philosophy of Kemalism. Its antiKemalist transformation under the AKP regime has been gradual; at no point did the Diyanet initiate a direct and proactive antagonism against the Kemalist state ideology. Rather, beginning with the Islamization of the content of sermons through the promotion of an Islamized version of Turkish nationalism (Saçmalı 2013, p. 73), and later the removal of Atatürk's and other secular Republican leaders' names from the sermons, Islamist ideas and narratives were introduced and Kemalist secularism slowly removed.

\subsection{Horizontal Aspect}

In the final stage of Islamization under Erdoğan, the list of "undesired citizens" of the Republic was expanded to include religious and ethnic minorities, white Turks (once the desired citizens of the Kemalist regime), liberals, leftists, Alevis, and disloyal Kurds, and even those practicing Muslims and Islamists not loyal to the regime, such as Gulenists, some Suleymancis, and other nonloyal/critical groups. The regime now categorized not only the Kemalist elite and their institutions as the "enemy", but increasingly all secular Kemalist Turks ("White Turks") were portrayed as "them": the groups that ill-treated and persecuted Islamists in the past and are still conspiring to destroy Islamists.

The Diyanet's evolving Islamism and opposition to secularism was demonstrated during the Gezi Park protests, an event that exposed a deep fault line in Turkish society. The protests began as part of a campaign against a project of rebuilding Ottoman-era military barracks in a park in Taksim, Istanbul's historical and touristic district. Taking advantage of some acts of violence by small provocative groups during mainly peaceful events, the regime allowed police to harshly and violently suppress protestors. Yet, despite the oppressive policies of the AKP government against the protest, Gezi generated a wider social movement opposing the authoritarian rule of the government. In response, and led by then Prime Minister Erdoğan, the AKP government insulted and demonized any groups participating in the Gezi demonstrations. The framing of the protests as antireligious by pro-AKP media played a key role in this demonization. In the pro-government media, which by 2013 dominated Turkish press and television media, participants in the Gezi protests were portrayed as "marauders", "anarchists", "disbelievers", and "terrorists"; in short, as enemies of "the people" (Muslim Turks). Pro-government media also suggested that "external forces", who desired chaos in Turkey and wished to stage a coup against the AKP government, were behind the Gezi Park demonstrations.

When political tension was at its peak, Mehmet Gormez, the President of Religious Affairs, did not remain neutral in the face of the AKP government's efforts to defame and demonize the demonstrators. Supporting the allegations that protesters who took shelter in a mosque while escaping from police violence during the Gezi Events were drinking alcohol and acting inappropriately in the mosque, he also claimed that he had watched the camera recordings inside the mosque and listened to the mosque officials, and that there were "other behaviors that no Muslim could accept" (Hurriyet 2013). The allegation of "drinking in the mosque", which Erdoğan insistently kept on the agenda at that time, was denied by the mosque official. The drinking images that Erdoğan promised to share with the public were never published, and the official who denied the allegations was appointed to another mosque (T24 2014). Later, a mosque imam in Istanbul spoke in the Friday sermon, referring to the participants of Gezi Park demonstrations, saying "in the time of our Prophet, the atheists and infidels were fought". He clarified this statement by 
adding, "we will not fight them, but we will make them all rational". Although opposition officials drew public and government attention to these comments, criticizing them, the Diyanet ignored the incident.

The discourse Erdoğan used to marginalize and demonize the Gezi Park protesters is also reflected in the Diyanet's sermons. Erdoğan, during the peak of the Gezi Park events, chose to divide the society into "us" - representing the side of right—and "them" representing the wrong. He also referred to his own electoral base in a threatening manner, remarking that I have difficulty in keeping my $50 \%$ of society at home who also want to pour into the streets (Hurriyet 2013). Erdoğan described the participants and supporters of the Gezi Park demonstrations as "looters", "vandals", and "terrorists", and repeated apparently false allegations that the demonstrators entered the mosque with beer bottles and attacked a woman wearing a headscarf. He also claimed that "some capital groups, interest lobbies, some media groups" linked to "the West" used the protests to attack Turkey's economy and stage a coup against his government (BBC 2013). In the sermon titled "Freedom and Responsibility", dated 28 March 2014, a hadith of the Prophet of Islam comparing the world to a ship and people to passengers was adapted to the agenda:

People are divided into two. People with knowledge, wisdom, and virtue, some of whom observe the limits set by God. The other part is the people who violate these boundaries, have been captured by their desires, who consider freedom as irresponsible, and who have a sense of freedom that will end up as a disaster for both themselves and humanity.

After the protests, social media became another target in the sermons. Through sermons, the Diyanet tried to create the perception that social media is a problematic and 'dangerous' area, and the government is right to censor and prohibit. For example, in the same sermon, while opponents were targeted as "those who pierced the bottom of the ship", it was also stated "Our world has shrunk with mass media, people who want to pierce the bottom of the ship have increased, they use technical means and go so far as to disrupt the ecological balance of nature". Diyanet statements such as this target social media platforms and users criticizing the government's authoritarian practices during the Gezi events. Indeed, this sermon was delivered just after the regime's disabled access to some social media platforms in March 2014.

The other group demonized in the sermons, to reinforce the regime's agenda, was the Kurds. On 16 February 2018, just before the Afrin Military Operation in Syria, a sermon explaining the meaning of "jihad" was delivered; a controversial topic, hitherto avoided by Diyanet. The sermon began with an explanation of the inner jihad and finished with an explanation of the external armed jihad, which is underscored as the "true meaning of jihad". The sermon also describes Turkish Armed Forces' Afrin Military Operation as an act necessary to protect the lives of Turkish Muslims, who are threatened by Kurdish armed groups. The purpose of this sermon was thus to-perhaps at a subconscious level—define Muslim majority Kurdish people living in Afrin as "enemies of Islam". For example, the sermon argued that,

If a believer succeeds in the jihad with one's own should, then s/he will succeed in the jihad against the enemies of Islam as well. [ . . . ] Today, we are striving with our lives and our wealth for existence as a nation. [ ... ] We all have our responsibilities in this struggle for survival [ ... ] O Allah! Grant victory to our heroic army who has been fighting for our independence and our future, for our unity and solidarity.

The head of the Diyanet, Ali Erbaş, himself also delivered the same sermon while on a trip to the southern Hatay province where he met with military officials coordinating the assault on the US-backed Kurdish People's Protection Units (YPG) in Afrin. Moreover, during the opening ceremony of a Qur'anic School, Ali Erbaş reportedly said, "I beg God's mercy and grace for our martyrs, and I beg God that our veterans heal very soon. 
We are opening Qur'anic Schools. They continue jihad over there and we do here, too" (Diken 2018).

Among the unwanted citizens and groups othered and demonized by the AKP government, the case of the Gulen Movement is quite illustrative. In Diyanet sermons, the Gulen Movement is always portrayed as the other-as "them", the enemy of the regime and the people, as "traitors" and "collaborators" with external enemies and "crusaders". The regime, through the instrumentalization of Diyanet sermons—and ultimately Islam-calls upon "the pure people" to fight against the "internal" enemies of Islam and the Islamist regime in Turkey. The Diyanet, at regular intervals, has promoted hate speech against the movement and its followers in Friday sermons, and has sought to disassociate the movement from Islam. The earliest criticism against the Gulen Movement in Diyanet sermons attacks their alleged fanaticism. The sermons implicitly portrayed sympathizers of the movement as people who consider themselves and their relation to the movement as a source of superiority over other religious groups in Turkey. ${ }^{5}$ One sermon, dated 5 June 2015, cautioned that "the number of those among Muslims who put their sect, disposition, race and ideology ahead of Islam isn't few". Diyanet sermons have continuously raised this topic of "prioritizing one's own group over belongingness to the global Muslim ummah" to criticize the movement. It is also worth noting that the Diyanet's vilification of the movement shows that it considers members of the movement outside the Islamic ummah. ${ }^{6}$

Over time, the Diyanet has intensified its efforts to portray the Gulen Movement as an opponent of Islam, claiming that its leader has reinterpreted or changed many aspects of the religion, and that his followers blindly obey him and thus fail to question any wrongdoing within the movement. The turning point in this shift to harsher criticism came after the 2016 coup attempt. Before the coup attempt, the Diyanet had minced its words and used mostly ambiguous and implicit criticism of the Gulen Movement, and avoided directly or explicitly targeting the movement, perhaps because the congregation also included Gulen members and supporters. After the coup attempt, however, the Diyanet changed its attitude sharply and joined the AKP's anti-Gulen campaign on all fronts. Before the coup attempt, the Gulen Movement was usually referred to in Diyanet sermons as an insider abroad (hariçteki dahil); after the coup attempt, the movement was called an outsider inside (dahildeki hariç). Another striking accusation brought against the movement by the Diyanet was that it caused sedition (fitne), was an instrument of the evil (şer), and promoted false teachings of Islam.

Following the coup attempt, sedition (fitne) and corruption/disorder (fesat) were frequently mentioned in the sermons. ${ }^{7}$ Of course, "sedition" is a generic word with broad utility in Islamic discourse, but the prime target of this conceptualization in the sermons has been the Gulen Movement, though it has also been invoked in conjunction with the violence and terrorist attacks perpetrated by the PKK. The concept of sedition was again mentioned with an increasing intensity in the sermons produced after the 17-25 December 2013 corruption scandals involving ministers and close associates of Erdoğan. ${ }^{8}$ This pattern is a clear indicator of the Diyanet's intention to raise the topic of sedition time after timeeven before the 15 July 2016 coup attempt—in its fight against the Gulen Movement.

In addition, the sermons also imply that the Gulen Movement does not belong to the Turkish homeland, and does not represent the nation. Post-coup-attempt sermons portray the movement as an external enemy that submits itself to the "invaders (müstevli)". One sermon, on 14 July 2017, reminded the congregants that "We have witnessed at the night of July 15 that the betrayal network which pretended to be righteous but exploited the religion, faith, values, feelings, charity of this nation for 40 years plotted the existence of this nation. Having stolen the children of the nation and spoiled a few generations this movement of dissension targeted the existence of our country in line with the agenda of invaders." 


\subsection{Civilizational Aspect}

In Diyanet sermons, the term "ummah" is not merely used to refer to Muslim communities and believers, it has a political dimension. "Ummah" in the sermons refers to a united transnational political identity, and by using this term, the regime aims to raise a political "awareness" and create a politically active community. For example, the sermon dated 4 November 2016 urges the "community of believers" to "rebuild the awareness of ummah today".

The victimhood of Muslims is very prominent in the formation of Ummah as a transnational political identity. The Diyanet has embraced this victimhood rhetoric in its sermons, portraying Muslims as victims of the West, which they accuse of opening "holes of fire in the Islamic territory". Without naming the exact enemy, the sermons often claim that all Muslims have been victimized by "some" enemies, enemies who even today are conspiring against Muslims, their religion, their unity, and their hopes. References to these unnamed enemies are kept obscure, and therefore are open to loading in parallel with changing context, especially in horizontal and vertical dimensions. In a majority of passive and hostility-loaded sentences in Friday sermons, the hidden subject refers to enemy(ies) of Muslims as Judeo-Christian Western civilization. For example, the sermon delivered on Friday, 26 January 2018 reads,

We have been going through certain trials as a nation and as the Islamic ummah in the recent years. Those who want to weaken us and to pit Muslims against Muslims are coming at us with the weapons of sedition, terror, and treachery. They are trying to pull our country in the pits of fire they opened in all corners of the Islamic geography. Our independence and future are targeted through various tricks and plots, plans and traps. They are trying to drive the Islamic ummah to despair by threatening our unity and peace.

Another sermon dated 11 October 2019 reads,

Unfortunately, the world today was turned into a place full of dark and evil traps. Those who claimed to bring so-called independence to some places have rather invaded those places ... Those who plan to dig pits of fire in all around the Islamic world have used weapons of sedition, terrorism, and betrayal to cause brothers to hit one another. Using various plots, plans, tricks and traps, they have targeted our existence and future survival, as well as our freedom and future. They have attempted to bring us, our noble nation to have been the flagbearer of the Muslim ummah for hundreds of years, to our knees.

In this sermon, no country or military force is named that may provide an answer to the question "by whom?" However, it is clear from the sentence that reads "to bring so-called independence to some places have rather invaded those places" that the problems of the so-called Muslim world are offloaded to the West, which becomes the hidden subject of the blame. In other words, the West is constructed as "the (real) enemy", and as the sponsor of all disasters in the "Muslim world".

While some sermons acknowledge the responsibility of Muslims themselves for the miserable state of the Islamic world, more often the plight of Muslims has been linked to malicious interventions of external (Western) powers. In one representative sermon, Muslims were reduced to passive victims of various "power centers". The Friday sermon dated 4 October 2014 reads as follows:

By looking at the conditions the believers live in, it should be known how the power centers [West] gather strength through the blood of the believers and how the brotherhood of faith that makes believers closer to each other is attacked and damaged and turned into fighting, violence and hostility [between Muslims].

Another sermon, dated 9 December 2016, blamed hegemonic powers for the destruction in Islamic countries, suggesting that "Because of the ambitions and power struggles of the hegemonic [Western] powers in our region, the Islamic lands are falling into ruins." 
The AKP's political turn against the West and towards identification with the "Muslim world" is also evident in sermons. Sermons invite the people to rally around the idea of realizing a Muslim heartland by supporting the Islamist regime and its leader, and by "standing against the oppressor as was done "the past":

If we, as the descendants of a nation which became the hope of humanity throughout history, extend our hands to the oppressed and the innocent with a spirit of unity. Let us stand against the oppressors and stand by the oppressed as we did in the past, regardless of their religion, color, and geography ... Let us always defend the right and the righteous even when the axis of evil come down on us with all its might, knowing that the prayers of the oppressed is our greatest power. (8 September 2017).

Alongside "the Western-inflicted victimhood of Muslims", the historical role or mission of Turkey as "the guardian of the ummah" appears frequently in the sermons. When this notion appears, Turkey is framed not only as the hope of the Muslim world but also a hope for all victimized people in the world, with one sermon asserting that "Sustaining its honorable journey from the past to the present, the existence of our noble nation is a hope for the world" (30 August 2019).

Another read,

Just as in the past, today, too, our nation will continue to be the remedy for the remediless people, be there for those people who has nobody by their side, and be the hope and safe haven for the victimized and the refugees (11 October 2019).

In these sermons, Turkey is presented as the hope and leader of the Muslim world. Using this civilizationist rhetoric, an imaginary fight between Islam and the Crusaders is constructed; or rather, the rhetoric suggests that this fight has continued unabated since the First Crusade of the 11th century. After 2011, civilizationalist notions of a Muslim religious brotherhood have become a focus of Diyanet preaching. These sermons promote Islam as a unifying force, and stress the underlying importance of strengthening the Islamic community in the interests of peace and harmony. In the early 2010s, the focus of the Diyanet's sermons was restricted to the Islamic world and the issues and problems concerning Muslims. The content of Friday sermons often contradicted the Diyanet head, Mehmet Görmez's, understanding of "interreligious dialogue", who suggested dialogue among religions on theological issues was all but pointless, but suggested religious leaders instead come together to discuss "remedies to solve problems of humanity" (AA 2013).

As Turkey severed its ties with the West and adopted a more Islamic, conservative and nationalist foreign policy - acting indeed like spokesman for the entire Islamic worldthe Diyanet also embraced a similar discourse, defining the relationship between Islamic territory and the rest of the world with terms and references like exploitation, suppression, and an endless state of conflict between good and bad (hak ile batıl).

The Diyanet's Friday sermons have not only drawn on the importance of Muslim community over national identities, but have also advanced the concept of Islamic territory. Sermons defined Islamic territory as a single entity in which Muslims should foster ummah consciousness and uphold the same values, principles, and objectives. One sermon hailing Islamic unity suggested that,

Vahdat [unity] means brotherhood, friendship, love, respect, cooperation, solidarity and sharing. Vahdat means having the consciousness of living together, coming together around common values, and heading towards common ideals. Vahdat means gathering under the banner of tawhid [oneness of God], leaving aside all interests in the way of Allah. Vahdat means making our existence, [our victories and defeat], our pain, our joys and our prayers common. Vahdat is to work with all our might to prevent the shedding of Muslim blood and the division of Muslims. (8 April 2016).

It is worth noting that in this context, tawhid (oneness of God) is presented in opposition to the trinity of Christianity. Muslims are invited to "gather under the banner of it", 
and against the Christian West (Muslims' civilizational other/enemy) and to work hard to prevent "the division of Muslims".

Vahdat, the discourse of "unity", has also entered the Diyanet literature during this Islamist populist period, and has become a highly popular concept. For example, during 2014-2020, Vahdat was mentioned in 21 sermons. Furthermore, the Diyanet explained the importance of unity to the congregation exclusively in one sermon in 2015, and in three sermons in 2016. These sermons highlighted the notion that the Islamic world is encircled by three great fires: sectarianism, racism, and terrorism. To return the Islamic civilization to its "old glorious days", to restore the asr- 1 saadet (the century of happiness), to prevent the "shedding of Muslim blood, and the division of Muslims", the sermon urges believers to unite under the umbrella of Islamic brotherhood and change "I" to "we" and work for Muslim unity (26 June 2015). This wording shows how the sermons attempt to instill the perception of an Islamic "we, the people". In the sermons, re-constructing the consciousness of being "one" ummah is emphasized. Muslims are defined as "members of a large family" who must work together within the framework of a common ideal in order to bring back the brilliant days of the Islamic civilization. For example, a sermon dated 15 April 2016 calls for cooperation among Muslims, and reads "... Today, as the ummah of Islam, let's work together to turn the lands of Islam back into a land of knowledge, wisdom and ingenuity." Another sermon, dated 23 February 2018, suggests it is a pity for "one to pass away without being able to use his/her qualifications and skills for the benefit of the society and the ummah."

It is also important to underline that "the past", a concept often invoked in the sermons, is an imagined version of the actual past, recreated by the Diyanet as pure and free from taints. One sermon, dated 21 July 2017, claims that Muslims have "no inhumane practices such as violations of rights, cruelty and savagery that will embarrass us in our history." Moreover, the sermon suggests, by returning to this imagined past, Muslims may yet become a "great nation [ummah] again".

Diyanet sermons put further blame on "others" by dramatizing the perception of threat against the Islamic world. One sermon implicitly referred to the clash of civilizations paradigm, while defining the extent of the assaults with the following sentences:

What happened in the Islamic geography today clearly shows the point reached by those who try to destroy our women, children, lives, values, history, culture and civilization. In Syria, Iraq, Yemen, Libya, Egypt, the unity of the ummah, the honor of the nation, the respect of the country has been trampled.

The Diyanet re-visited "the attacks against religion, belief and values" discourse in another sermon, stating that "Throughout history, attempts to damage and destroy our religion, belief, and values could not harm the truth of Islam".

The Diyanet's one-sided advocacy of Muslims and their culture, rights, and values has sometimes amounted to hypocrisy. Despite outcry against the breaches and assaults against the Islamic world and Muslims, the Diyanet has turned a blind eye to similar attacks that targeted non-Muslims and has adopted an ambiguous language that may lead to the perception that such crimes are only objectionable or a source of concern when they are committed against Muslims. After a terrorist attack at mosques in New Zealand claimed the lives of 49 Muslims on 15 March 2019, the Diyanet rushed to condemn this incident but instead of seizing this occasion to express a message defying violence as a matter of principle, Diyanet stressed that,

It should be well known that any attack on our temples and Muslims is unacceptable wherever they are in the world, no matter who they come from, or for whatever reason. In the face of such provocative incidents, it is in the characteristics of Muslims to act with common sense...

The Diyanet's religious and cultural selectivism has been accompanied by calls for all Muslims to ignore all difference, including sect, race, language, ideology, and geography, and to unite "as a single body" against those attacks against the Islamic geography. One sermon suggested Muslims take lessons from the Battle of Karbala to strengthen the unity 
and brotherhood and to give a necessary response to those who want to re-inflict pain, open deep wounds in the hearts of Muslims, and turn shared values into division, hatred and animosity. "We should give the necessary answer with one heart to those who want to make us relive the pain of the past, open nonhealing wounds in our hearts, and turn our common values into separation, and hatred". Another sermon urged the congregants:

One of the most important duties of Muslims is to be one voice against unbelief and to be united before the oppressor. However, it is possible to achieve this by basing not on each other's sect, legitimacy, race, language, geography and ideology, but Islam's understanding of oneness and unity. The road to unity, amity and peace; the way to know the friend and the enemy; make the ummah smile, not the others [the Western powers] pass from here.

In using the phrase "not the others pass from here", the sermon is referring to invasions of Muslim regions by Western countries, invoking the weakness of the ummah when disunited.

In some sermons, this call for unity and action is embedded in jihad rhetoric. In the aftermath of Turkish Armed Forces' offensive into Syria in October 2019, one sermon invoked Islamic principles to justify this operation. The sermon claimed,

... . believers never consent to the violation of the values of which the religion of Islam regards as sacred and untouchable, such as the occupation of homelands and homes. They do not hesitate to launch an honorable struggle to correct the deteriorating balances, to establish an environment of peace and to ensure justice.

In another sermon, which coincided with Turkey's military operations in Afrin, Turkey and the Islamic ummah were portrayed as one, and as a single target of external attacks, and urged unity among Muslims to ward off these attacks. The sermon warned the congregants that,

In recent years, we have been passing through the circle of testing both as the ummah of Islam and with our nation. Those who want to weaken our power and to it, brothers to brothers [Muslims to Muslim] come to us with the weapon of mischief, terror and betrayal. Our country is trying to be drawn into the fire pits opened in all corners of the Islamic geography. Our existence and survival, our independence and our future are targeted with various tricks and deceptions, plans and traps. By threatening our unity and vitality, the hopes of the Islamic ummah are actually being consumed.

Other sermons have blamed Western powers for all bloodshed. One sermon asks congregants, as a guiding question, "Isn't the greed of global powers the cause of the bloodshed and suffering in our geography?" Another sermon, in January 2018, claimed "For the sake of the greed, interests and power struggle of the ruling powers in our region, the Islamic lands are turning into ruins."

While the Diyanet has promoted the "us" versus "them" rhetoric, it has also been attentive to emboldening the line between values and symbols of this rhetoric. One symbolic about-turn in Friday sermons policy related to the question of how Muslims should approach the Gregorian New Year. For example, in 2011, the New Year sermon was positive, stating "Firstly we wish our country, geography, the Islamic world, and all people peace, tranquillity and happiness, we hope this year will bring wealth and fruitfulness." But by the following year, the sermon criticized the celebration of the New Year, stating that,

It is sorrowful to see that our culture has been converted to a consumption culture that belongs to another religion, another culture and another world that celebrates the New Year. Moreover, the future of our children's identity is under cultural erosion.

Under the AKP regime, the concept of nation was steadily replaced in Friday sermons with the concept of the ummah. In making this change, the Diyanet placed heavy emphasis on the civilizational aspect of Turkish Muslim identity and on Muslim people in the political geography of Islam (i.e., the Muslim world). The sermons have constructed an antagonistic dichotomy between the Islamic and Western civilizations and Turkey has been presented as the defender of the Islamist civilization against the Crusader West. 


\section{Conclusions}

In this article, and drawing on the relevant populism literature, we critically examined the Turkish Diyanet's weekly Friday sermons through the lens of populism as a novel contribution to the relevant literature on Turkey. However, the article is also intended as a general contribution to the scholarship on religion and populism, insofar as it shows how a populist leader-in this case Recep Erdoğan-systematically uses relevant state institution(s) for the purpose of communicating and disseminating their religious populist rhetoric and appeal.

The paper demonstrated how the sermons have been instrumentalized by the AKP in order to construct a populist narrative and to propagate Erdoğanist Islamist populism in Turkey. We observed that through the Friday sermons, the majority-Sunni Muslim Turks are presented with statements that evoke negative emotions and play on their specific fears, their sense of victimhood, and through which their anxieties-real and imaginedare revived and used to construct populist binaries to construct and mobilize the people in support of an authoritarian Islamist regime purported to be fighting a "civilizational enemy" on behalf of "the people".

Our analysis of the sermons reveals that the Diyanet functions as a tool of the Erdoğanist Islamist regime, with which they construct and propagate multidimensional (vertical, horizontal, and civilizational) populist binaries. We argued that in the Diyanet's Friday sermons, vertical populist binaries are employed to justify Erdoğan's fight against the Kemalist establishment-particularly in the early years of AKP rule-while horizontal binaries are invoked to galvanize popular support for Erdoğan's crackdown on political opposition, especially on liberal and secular elements of Turkish society. These horizontal and vertical binaries are hosted within a wider civilizational frame and binary within the Diyanet's Friday sermons, where they are employed to construct a constitutive "other" against which the regime can define "the people". The designated vertical and horizontal enemies are also linked, as collaborators, to the civilizational enemy of "the pure people" of the country. In other words, the Friday sermons depict disloyal Islamic groups, Kurds, seculars, and liberal leftists as extensions or collaborators of the civilizational enemy, the Judeo-Christian West. According to the Friday sermons, these groups are constantly collaborating with "the civilizational enemy", orchestrating "coups" and continuously conspiring against Islam and Muslims. Most importantly, our paper highlighted the hosting role/function of the civilizational aspect within the religious populism of the AKP. We showed how the vertical and horizontal aspects of the regime's populist narrative were employed in the sermons within the civilizational aspect: "the people" and "the enemy" are both constructed within the broader Islam versus Judeo-Christian West civilizational frame. Thus, in the AKP's configuration of populism, the civilizational dimension plays a hosting role for the Islamist populist campaign carried out in Friday sermons of the Diyanet.

Author Contributions: Conceptualization, I.Y., M.D. and N.M.; methodology, I.Y., M.D. and N.M. investigation, I.Y., N.M. and M.D.; resources, I.Y., and M.D.; data curation, I.Y. and M.D.; writingoriginal draft preparation, I.Y. and M.D.; writing-review and editing, I.Y., N.M. and M.D.; project administration, I.Y.; internal funding acquisition, I.Y. All authors have read and agreed to the published version of the manuscript.

Funding: This research received no external funding.

Conflicts of Interest: The authors declare no conflict of interest.

\section{Notes}

1 Binaries in horizontal and vertical dimensions are created with direct or indirect reference to the binaries inherited or constructed in the civilizational dimension. Thus, success of constructed vertical and horizontal binaries relies on credibility of these direct or indirect references to their civilizational extensions. Therefore, we call the civilizational aspect "the hosting dimension" of religious populism.

2 Friday as a day and the Friday prayer have a significant place in Muslim religious life, and the Friday sermons are an inseparable aspect of this weekly prayer. In addition to their focus on the ethical and religious formation of the 
community, the Friday sermons also play a significant role in uniting the community both socially and politically. Today, Friday sermons continue to have a special religious status among Muslims, and attendees are forbidden to speak among themselves during the delivery of sermons; anyone who speaks, or even asks another person not to speak, will be acting against the Islamic law. Therefore, more than a discussion or speech, it is delivered in the form of imposition in a top-down fashion.

3 Elevation of the President of the Diyanet (başkan) from directorate to permanent secretary (müsteşar), and the state protocol of Diyanet director's hierarchy being elevated from 51 to 10 by the AKP can be considered both symbolically and practically one of the greatest prerogatives given to the society's conservative segments. This new status of the Diyanet and its increased budget allowed the Diyanet to establish radio and television channels. The Diyanet's mandate was expanded to provide religious services outside mosques, including, for example, in institutions, such as hospitals, prisons, retirement homes, and women's shelters. Also, the Diyanet controls approximately 90,000 mosques and generates the Friday sermon, which all mosques in Turkey deliver in its exact form.

4 Diyanet İşleri Başkanlığ 20 Haziran 2014, “Camiye koşalım, Kuran'la buluşalım” https:/ / ankara.diyanet.gov.tr/ Sayfalar/contentdetail.aspx?MenuCategory=Kurumsal\&contentid=241 (accessed on 17 May 2021).

5 In the sermon entitled "Islam Refuses Every Kind of Racisms" (5 June 2015), it was said that "sometimes people consider their own school of thought, identity, movement superior than others ... this is equal to preferring division and discrimination over unity and togetherness".

6 See especially the sermons on the following dates: 1 January 2016, 15 January 2016, 22 April 2016, 26 July 2016, 3 November 2017, 23 November 2018.

7 Since 2010, the Qur'anic term sedition/fitne occurs 81 times, corruption and disorder/fesat' 30 times, and the word division/tefrika 8 times. Clearly the Diyanet places great emphasis not only on brotherhood and unity but also on the danger of disunity, sedition, and corruption on the rhetorical level.

8 The number of sermons that included the word sedition over the years: 2010: 1, 2011: 0, 2012: 3, 2013:4, 2014: 8, 2015 : 17, 2016: 11, 2017:8, 2018: 9, and 2019: 9.

\section{References}

AA. 2013. Dinlerarası Diyalog Kavramı Yeniden ele Alnmalı, Anadolu Ajansi. May 30. Available online: https://www.aa.com.tr/tr/ turkiye/dinlerarasi-diyalog-kavrami-yeniden-ele-alinmali/241452 (accessed on 14 May 2021).

Açıkel, Fethi. 1996. Kutsal Mazlumluğun Psikopatalojisi. Toplum ve Bilim 70: 153-74.

Adak, Sevgi. 2021. Expansion of the Diyanet and the Politics of Family in Turkey under AKP Rule. Turkish Studies 22: 200-21. [CrossRef]

Aytaç, S. Erdem, and Ziya Öniş. 2014. Varieties of populism in a changing global Context: The divergent paths of Erdoğan and Kirchnerismo. Comparative Politics 47: 41-59. [CrossRef]

Barr, Robert R. 2009. Populists, Outsiders and Anti-Establishment Politics. Party Politics 15: 29-48. [CrossRef]

Bashirov, Galib, and Ihsan Yllmaz. 2020. The rise of transactionalism in international relations: Evidence from Turkey's relations with the European Union. Australian Journal of International Affairs 74: 165-84. [CrossRef]

BBC. 2013. Erdoğan: Gezi Parkıgösterilerikhlı. June 11. Available online: https://www.bbc.com/turkce/haberler/2013/06/130611 Erdoğan_gezi_konusmasi (accessed on 14 May 2021).

Berkes, Niyazi. 1999. The Development of Secularism in Turkey, 1st ed. New York: Routledge. [CrossRef]

Bozkurt, Umut. 2013. Neoliberalism with a human face: Making sense of the justice. Science and Society 77: 372-96. [CrossRef]

Brubaker, Rogers. 2017. Between nationalism and civilizationism: The European populist moment in comparative perspective. Ethnic and Racial Studies 40: 1191-226. [CrossRef]

Canovan, Margareth. 2002. Taking Politics to the People: Populism as the Ideology of Democracy. In Democracies and the Populist Challenge. Edited by Yves Meny and Surel Yves. New York: Palgrave, pp. 25-44.

Çapan, Zeynep Gülşah, and Ayşe Zarakol. 2019. Turkey's ambivalent self: Ontological insecurity in 'Kemalism' versus 'Erdoğanism'. Cambridge Review of International Affairs 32: 263-82. [CrossRef]

Castaldo, Antonino. 2018. Populism and Competitive Authoritarianism in Turkey. Southeast European and Black Sea Studies 18: 467-87. [CrossRef]

CNN. 2016. Donald Trump: 'I Think Islam Hates Us'. March 10. Available online: https://edition.cnn.com/2016/03/09/politics/ donald-trump-islam-hates-us/index.html (accessed on 14 May 2021).

Demiralp, Seda. 2012. White Turks, Black Turks? Faultlines beyond Islamism versus secularism. Third World Quarterly 33: 511-24. [CrossRef]

Diken. 2018. Diyanet'egöre Afrin Harekatı 'Cihat'. January 29. Available online: http:/ /www.diken.com.tr/diyanete-gore-afrin-harekaticihat/ (accessed on 14 May 2021).

Dinçşahin, Şahin. 2012. A symptomatic analysis of the justice and development Party's populism in Turkey, 2007-2010. Government and Opposition 47: 618-40. [CrossRef]

Göle, Nilufer. 1997. Secularism and Islamism in Turkey: The Making of Elites and Counter-Elites. Middle East Journal 51: 46-58.

Gözaydın, İştar. 2008. Diyanet and Politics. The Muslim World 98: 216-27. [CrossRef] 
Grigoriadis, Ioannis N., and Esra Dilek. 2018. Struggling for the Kurdish vote: Religion, ethnicity and victimhood in AKP and BDP/HDP rally speeches. Middle Eastern Studies 54: 289-303. [CrossRef]

Günay, Cengiz, and Vedran Dzihic. 2016. Decoding the authoritarian code: Exercising 'legitimate'power politics through the ruling parties in Turkey, Macedonia and Serbia. Southeast European and Black Sea Studies 16: 529-49. [CrossRef]

Haber Turk. 2015. Türkiye'de Cuma Namazı Kılanların Sayısı 15 Milyon. March 7. Available online: https://www.haberturk.com/ gundem/haber/1050703-turkiyede-cuma-namazi-kilanlarin-sayisi-15-milyon (accessed on 16 May 2021).

Haynes, Jeffrey. 2020. Right-Wing Populism and Religion in Europe and the USA. Religions 11: 490. [CrossRef]

Hurriyet. 2013. Diyanet Isleri Baskani Mehmet Gormez O Caminin 3 Gunluk Kayitlar Elimizde. July 24. Available online: https://www. hurriyet.com.tr/gundem/diyanet-isleri-baskani-mehmet-gormez-o-caminin-3-gunluk-kayitlari-elimizde-24359184 (accessed on 14 May 2021).

Hurriyet. 2020. Diyanet Head's Sermon at Hagia Sophia Stirs Debate. July 26. Available online: https://www.hurriyetdailynews.com/ diyanet-heads-sermon-at-hagia-sophia-stirs-debate-156881 (accessed on 14 May 2021).

Jagers, Jan, and Stefaan Walgrave. 2007. Populism as political communication style: An empirical study of political parties' discourse in Belgium. European Journal of Political Research 46: 319-45. [CrossRef]

Katsambekis, Giorgos. 2020. Constructing 'the people' of populism: A critique of the ideational approach from a discursive perspective. Journal of Political Ideologies, 1-22. [CrossRef]

Kili, Suna. 1980. Kemalism in Contemporary Turkey. International Political Science Review 1: 381-404. [CrossRef]

Kinnvall, Catarina. 2019. Populism, ontological insecurity and Hindutva: Modi and the masculinization of Indian politics. Cambridge Review of International Affairs 32: 283-302. [CrossRef]

Kirdiş, E., and Amina Drhimeur. 2016. The Rise of Populism? Comparing Incumbent Pro-Islamic Parties in Turkey and Morocco. Turkish Studies 17: 599-617. [CrossRef]

Laclau, Ernesto. 2006. Why Constructing a People Is the Main Task of Radical Politics? Critical Inquiry 32: 646-80. [CrossRef]

Lord, Ceren. 2018. Religious Politics in Turkey: From the Birth of the Republic to the AKP. Cambridge: Cambridge University Press.

Marzouki, Nadia, Duncan McDonnell, and Oliver Roy, eds. 2016. Saving the People: How Populists Hijack Religion. Oxford: Hurst.

Moffit, Benjamin. 2017. Transnational Populism? Representative Claims, Media and The Difficulty of Constructing A Transnational "People". Javnost: The Public 24: 409-25. [CrossRef]

Morieson, Nicholas. 2021. Religion and the Populist Radical Right: Christian Secularism and Populism in Western Europe. Wilmington and Malaga: Vernon Press.

Mudde, Cas. 2004. The Populist Zeitgeist. Government and Opposition 39: 541-63. [CrossRef]

Mudde, Cas. 2017. Populism: An Ideational Approach. In The Oxford Handbook of Populism. Edited by Cristóbal Rovira Kaltwasser, Paul Taggart, Paulina Ochoa Espejo and Pierre Ostiguy. Oxford and New York: Oxford University Press.

Öktem, Kerem. 2012. Global Diyanet and Multiple Networks: Turkey's New Presence in the Balkans. Journal of Muslims in Europe, 27-58. [CrossRef]

Özçetin, Burak. 2019. The Show of the People' against the Cultural Elites: Populism, Media and Popular Culture in Turkey. European Journal of Cultural Studies 22: 942-57. [CrossRef]

Özpek, Burak Bilgehan, and Nebahat Tanriverdi Yaşar. 2018. Populism and foreign policy in Turkey under the AKP rule. Turkish Studies 19: 198-216. [CrossRef]

Öztürk, Ahmet Erdi. 2018. Transformation of the Turkish Diyanet both at Home and Abroad: Three Stages. European Journal of Turkish Studies. [CrossRef]

Öztürk, Ahmet Erdi, and Semiha Sözeri. 2018. Diyanet as a Turkish Foreign Policy Tool: Evidence from the Netherlands and Bulgaria. Politics and Religion, 1-25. [CrossRef]

Ozzano, Luca, and Fabio Bolzonar. 2020. Is Right-wing Populism a Phenomenon of Religious Dissent? The Cases of the Lega and the Rassemblement National. International Journal of Religion 1: 45-59. [CrossRef]

Peker, Efe. 2019. Religious Populism, Memory, and Violence in India. New Diversities 17: 23.

Poblete, Mario E. 2015. How to assess populist discourse through three current approaches. Journal of Political Ideologies 20: 201-18. [CrossRef]

Poulton, Hugh. 1997. Top Hat, Grey Wolf and Crescent. London: Hurst \& Company.

Roy, Oliver. 2016. Beyond Populism: The Conservative Right, The Courts, The Churches and the Concept of a Christian Europe. In Saving the People: How Populists Hijack Religion. Edited by McDonnell Roy Marzouki. London: C. Hurst \& Co.

Saçmalı, Muhammet Habib. 2013. Compliance and Negotiation: The Role of Turkish Diyanet in the Production of Friday Khutbas. Ph.D. Thesis, Bogaziçi University, Istanbul, Turkey.

Sawae, Fumiko. 2020. Populism and the Politics of Belonging in Erdoğan's Turkey. Middle East Critique 29: 259-73. [CrossRef]

Selçuk, Orçun. 2016. Strong presidents and weak institutions: Populism in Turkey, Venezuela and Ecuador. Southeast European and Black Sea Studies 16: 571-89. [CrossRef]

Sunier, Thijl, Heleen van der Linden, and Eleen van de Bovenkamp. 2016. The Long Arm of the State? Transnationalism, Islam, and nation-Building: The Case of Turkey and Morocco. Contemporary Islam 10: 401-20. [CrossRef]

T24. 2014. Camide Icki Ictiler Iddiasini Yalanlayan Muezzin Tesekkur Beklerken Tenzil Edildim. T24. November 22. Available online: https://t24.com.tr/haber/camide-icki-ictiler-iddiasini-yalanlayan-muezzin-tesekkur-beklerken-tenzil-edildim,277963 (accessed on 14 May 2021). 
Taguieff, Pierre-André. 1995. Political Science Confronts Populism: From a Conceptual Mirage to a Real Problem. Telos 103: 9-43. [CrossRef]

Tas, Hakki. 2020. The Chronopolitics of National Populism. Identities. [CrossRef]

Tuğal, Cihan. 2002. Islamism in Turkey: Beyond Instrument and Meaning. Economy and Society 31: 85-111. [CrossRef]

Türk, Hasan Bahadir. 2018. Populism as a medium of mass mobilization: The case of Recep Tayyip Erdoğan. International Area Studies Review 21: 150-68. [CrossRef]

Umar, Sanober. 2019. Constructing the "Citizen Enemy:" The Impact of the Enemy Property Act of 1968 on India's Muslims. Journal of Muslim Minority Affairs 39: 457-77. [CrossRef]

Wojczewski, Thorsten. 2020. 'Enemies of the people': Populism and the politics of (in)security. European Journal of International Security 5: 5-24. [CrossRef]

Yabanci, Bilge. 2016. Populism as the Problem Child of Democracy: The AKP's Enduring Appeal and the Use of Meso-Level Actors. Southeast European and Black Sea Studies 16: 691-17. [CrossRef]

Yabanci, Bilge. 2020. Fuzzy Borders between Populism and Sacralized Politics: Mission, Leader, Community and Performance in 'New' Turkey. Politics, Religion E Ideology 21: 92-112. [CrossRef]

Yabanci, Bilge, and Dane Taleski. 2018. Co-opting religion: How ruling populists in Turkey and Macedonia sacralise the majority. Religion, State $\mathcal{E}$ Society 46: 283-304. [CrossRef]

Yilmaz, İhsan. 2005. State, Law, Civil Society and Islam in Contemporary Turkey. Muslim World 95: 385-411. [CrossRef]

Yilmaz, İhsan. 2015. Kemalizm'den Erdoğanizm'e: Türkiye'de Din, Devlet and Makbul Vatandaş. Istanbul: Ufuk.

Yilmaz, Zafer. 2017. The AKP and the Spirit of the 'New' Turkey: Imagined Victim, Reactionary Mood, and Resentful Sovereign. Turkish Studies 18: 482-513. [CrossRef]

Yilmaz, Ihsan. 2018. Islamic Populism and Creating Desirable Citizens in Erdoğan's New Turkey". Mediterranean Quarterly 29: 52-76. [CrossRef]

Yilmaz, Ihsan. 2021. Creating the Desired Citizen Ideology, State and Islam in Turkey. Cambridge: Cambridge Univeristy Press.

Yilmaz, Ihsan, and Galip Bashirov. 2018. The AKP after 15 years: Emergence of Erdoğanism in Turkey. Third World Quarterly 39: 1812-30. [CrossRef]

Yılmaz, İhsan, Mehmet Efe Çaman, and Galip Bashirov. 2020. How an Islamist Party Managed to Legitimate Its Authoritarianisation in the Eyes of the Secularist Opposition: The Case of Turkey. Democratization 27: 265-82. [CrossRef]

Zúquete, Jose Pedro. 2017. Populism and Religion. In The Oxford Handbook of Populism. Edited by Cristóbal Rovira Kaltwasser, Paul Taggart, Paulina Ochoa Espejo and Pierre Ostiguy. Oxford: Oxford University Press.

Zürcher, Erik-Jan, and Heleen van der Linden. 2004. Searching for the Fault Line in Netherlands Scientific Council for Government Policy. The European Union, Turkey and Islam, 83-174. [CrossRef] 